\title{
Multi-dimensional well-being associated with economic dependence on ecosystem services in deltaic social-ecological systems of Bangladesh
}

\author{
Helen Adams ${ }^{1}$ (1) $\cdot$ W. Neil Adger ${ }^{2} \cdot$ Sate Ahmad ${ }^{3} \cdot$ Ali Ahmed $^{4} \cdot$ Dilruba Begum $^{5} \cdot$ Zoe Matthews $^{6}$. \\ Mohammed Mofizur Rahman ${ }^{7} \cdot$ Kristine Nilsen $^{8} \cdot$ Georgina Grace Gurney $^{9} \cdot$ Peter Kim Streatfield $^{3}$
}

Received: 16 December 2018 / Accepted: 16 February 2020 / Published online: 25 March 2020

(C) The Author(s) 2020

\begin{abstract}
While the benefits humans gain from ecosystem functions and processes are critical in natural resource-dependent societies with persistent poverty, ecosystem services as a pathway out of poverty remain an elusive goal, contingent on the ecosystem and mediated by social processes. Here, we investigate three emerging dimensions of the ecosystem service-poverty relationship: economic contribution of provisioning ecosystem services to the household livelihood mix, social-ecological systems producing different bundles of ecosystem services and material wealth versus reported life satisfaction. We analyse these relationships in Bangladesh, using data from a bespoke 1586-household survey, stratified by seven social-ecological systems in the delta coastal region. We create poverty lines to ensure comparability with traditional poverty measures that overlook environmental factors and subjective measurements of well-being. We find that any contribution of ecosystem service-based income to the livelihood mix decreases the likelihood of the incidence of poverty, and of individuals reporting dissatisfaction. We find no relationship between the incidence of material poverty and the specific social-ecological systems, from agriculture to fishery-dominated systems. However, the probability of the household head being dissatisfied was significantly associated with social-ecological system. Individuals living in areas dominated by export-oriented shrimp aquaculture reported lower levels of life satisfaction as an element of their perceived well-being. These results highlight the need for social policy on poverty that accounts for the diversity of outcomes across social-ecological systems, including subjective as well as material dimensions of well-being. National poverty reduction that degrades ecosystem services can have negative implications for the subjective wellbeing of local populations.
\end{abstract}

Keywords Poverty $\cdot$ Subjective well-being $\cdot$ Reported life satisfaction $\cdot$ Livelihood diversification $\cdot$ Agriculture $\cdot$ Aquaculture

This article is part of the Topical Collection on Sustainability of socialecological systems

Electronic supplementary material The online version of this article (https://doi.org/10.1007/s10113-020-01620-x) contains supplementary material, which is available to authorized users.

Helen Adams

helen.j.adams@kcl.ac.uk

1 Geography, King's College London, London, UK

2 Geography, College of Life and Environmental Sciences, University of Exeter, Exeter, UK

3 Faculty of Agricultural \& Environmental Sciences, University of Rostok, Rostock, Germany

4 Initiative for Climate Change and Health, International Centre for Diarrhoeal Disease Research Bangladesh, Dhaka, Bangladesh
5 Faculty of Economics, Ritsumeikan University, Kyoto, Japan

6 Social Statistics and Demography, University of Southampton, Southampton, England

7 Institute for Technology and Resources Management in the Tropics and Subtropics, Cologne University of Applied Sciences, Cologne, Germany

8 WorldPop, Geography and Environment, University of Southampton, Southampton, UK

9 ARC Centre of Excellence for Coral Reef Studies, James Cook University, Townsville, Australia 


\section{Introduction}

Despite rapid urban growth, many of the world's poor still live in rural areas and are dependent on natural resources for their income. Ecosystem services is a concept that explicitly considers the benefits humans gain from the natural environment, so that such benefits can be incorporated into economic valuations and management for sustainability. Often, the concept is brought to bear to provide economic reasoning for conservation (Pascual and Howe 2018) in low-income settings, and shows that conservation can also have positive benefits for the well-being of those dependent on the resources (Howe et al. 2013). Often, there are difficult trade-offs to be made between types of ecosystem services, benefits and users at different temporal and spatial scales (Schreckenberg et al. 2018).

However, many populations with high levels of poverty are not necessarily clustered in areas of high ecological significance. Rather, such populations often have already experienced rapid land use change and degradation associated with, for example, land intensification, the switch from subsistence farming to cash crops and increased influence of agricultural and resource exports. In such locations, increased productivity has been at the expense of underlying supporting ecological processes, which combined with the impacts of climate change, has led to the degradation of natural resources (e.g. Hossain et al. 2016). There is growing evidence that environmental degradation is amplified in open access or common pool resources, in the absence of alternative livelihood options and social safety nets for poorer populations (e.g. Fisher et al. 2014). Environmental degradation combined with increased influence of volatile commodity markets, therefore, means that rural livelihoods are mixed and dependent on a range of off-farm activities and often migration (e.g. Blaikie et al. 2002). Populations rely on remittances from migration to other areas, income from cottage industries and small businesses and selling labour in sectors such as construction and transport (Bebbington 2000; Rigg et al. 2018). Exploitation of the natural environment has led to some development gains (Raudsepp-Hearne et al. 2010), but benefits are clearly not widely distributed.

The relationship between natural resources and wellbeing is complex. Agriculture often remains the cornerstone of rural livelihoods, but rarely serves as a pathway out of poverty (e.g. World Bank 2016). High economic dependence on ecosystem services can be associated with both extreme poverty and a lack of poverty depending on the level of assets and entitlements. Extreme poverty can be found in the landless and jobless who rely on openaccess or common pool resources or agricultural wage labour while living in a state of precarity; a lack of poverty is seen in large land-owning farmers who can enter high-end, high-return agri-business (Toufique and Turton 2003). Thus, incomes based on open access resources such as fisheries can be both a cause and consequence of poverty and exclusion (Béné 2003).

Looking forward, the role of the natural environment in improving living conditions for the rural poor, and generating pathways out of poverty, is uncertain. This paper takes an ecosystem service perspective and investigates whether some of the ambiguity in the relationship between ecosystem services and positive livelihood trajectories is the result of different proportions of provisioning ecosystem services in the livelihood mix, an element that has yet to be interrogated systematically. We control for three other key factors well understood to influence how benefits are accrued by users: (1) the bundled (not random) distribution of ecosystem services and spatial differences in their availability (e.g. Hamann et al. (2015)), (2) social processes that mean uneven access to those ecosystem services that are available (e.g. Hicks and Cinner (2014)) and (3) different well-being indicators (e.g. Gough and McGregor (2007)). Since many households diversify their livelihood and utilise many different services, we analyse the poverty-ecosystem service relationship by social-ecological system rather than individual ecosystem services and benefits to allow for a suite of services and benefits to be used simultaneously.

Using bespoke household survey data from the from Ganges-Meghna-Brahmaputra delta, on the south and southwest coast of Bangladesh (Adams et al. 2016a, b), we run logistic regression models to predict material poverty (defined by the ability of household to meet cost of basic needs) and low reported life satisfaction (current and future reported life satisfaction of household head below 4 on a 10-point scale) from the percentage of household income originating directly or indirectly from provisioning ecosystem services. We stratify our sample by social-ecological systems, operationalised using satellite imagery and geographic information systems. Within the model, we control for social mechanisms that mediate the relationship between ecosystem service availability and well-being (e.g. Fedele et al. 2017), focusing on risk spreading strategies of assets, loans, migration and patronclient relationships.

\section{Well-being from ecosystem services in complex delta social-ecological systems}

\section{Material poverty and subjective well-being}

Poverty reduction strategies have focused on measuring material poverty, for example, headcount ratios and the number of people living below the poverty line, defined by the ability of the household to meet its basic needs. It is important to analyse such poverty lines in the context of transitory poverty, depth of poverty, inequality and multi-dimensional poverty. For example, households can move into, and out of, poverty 
over time, and as such, assessments consider the risk of falling into poverty (e.g. through sickness of the main income earner) (McCulloch and Baulch 2000). Another key dimension is the depth of poverty; a poverty line obscures the differences in conditions in households classified as under the line. For example, the ultra-poor (those in the bottom wealth quintile) tend not to benefit from poverty reduction strategies due to their marginalised position in society (Lenhardt and Shepherd 2013).

Furthermore, relational aspects are important given that absolute poverty often is less important in terms of a range of well-being outcomes than relative poverty (Cojocaru 2016). Decreases in average poverty can obscure, and are potentially outweighed by, increasing levels of inequality between and within nations, for example, measured through the Gini coefficient. Measures of material conditions are commonly supplemented by other dimensions of well-being such as health and education (Alkire and Foster 2011). Yet, poverty lines and headcount ratios remain key indicators: they are standardised measures of poverty, generated using easily and universally available data, that allow comparison between different places and allow progress to be tracked over time.

Such headcount ratios have been used extensively to investigate the link between natural resource use and poverty (Carter and Barrett 2006) and by the Bangladesh government in its own assessment of poverty (Toufique and Belton 2014). However, they do not address issues surrounding poverty dynamics or depth of poverty described above. The comparability of standard headcount measures aligned with culturally calibrated poverty lines leads. This study focuses on households and the distribution of poverty across social-ecological systems, but maintaining comparability with standard headcount measures and culturally calibrated poverty lines. Other studies focus beyond the household by examining dynamics within households to explain, for example, livelihood diversification and food consumption (e.g. Ellis 1998; Klasen and Lahoti 2016).

However, material conditions alone are not sufficient to create the 'good life'; that is to say, high levels of welfare, or happiness, often termed subjective well-being. Subjective well-being represents "all of the various evaluations, positive and negative, that people make of their lives, and the affective reactions to their experiences" (OECD 2013; p. 10) and is usually defined by a cognitive (evaluative), affective (emotional) and eudaimonic (meaning-based) elements. Development interventions aim to generate material well-being not for its own end but to improve wider subjective well-being (but the two dimensions only partially correlate (Diener and Tay 2015). Thus, it is crucial to measure not just material improvement but whether those material improvements are able to assist in the target population meeting their own life objectives. Subjective well-being forms one element of multi-dimensional well-being, along with health, education and good social relations, but is also impacted by these factors.

There are different approaches to understanding the subjective elements of well-being. Approaches that draw from economic ideas of happiness as welfare or utility analyse the relative value to the individual of different physical, social and psychological needs being met. They identify objective life domains such as health, income and relationships and focus on understanding their relative importance, as well as individual and group differences in preferences (e.g. Gough and McGregor 2007; Camfield and Esposito 2014; McGregor et al. 2015). Research that draws on Sen's (2001) capability approach conceptualises human well-being as the ability to take part in society in a meaningful way. Here, subjective well-being results from processes such as equality of opportunity, personal freedoms, human agency, self-efficacy, an ability to self-actualise, dignity and relatedness to others (e.g. Nussbaum 2001; Markussen et al. 2017; Hojman and Miranda 2018). Psychological perspectives focus on individual differences in experiences of subjective well-being based on personality traits, inherited predisposition and previous experiences (e.g. Diener et al. 2017). Other scholars have stressed the importance of relational aspects that take into account that people are embedded in multiple different relationships and that levels of well-being are contingent on the context (White 2017).

In the absence of a straightforward way of assessing all these contributors to subjective well-being, self-reported measurements of global life satisfaction ask the person to make an overall assessment of how well they think they have met their own life objectives, weighting different elements themselves (e.g. Diener et al. 2013). Measures of reported life satisfaction allow for a simple quantitative measurement of subjective well-being that can be included in larger questionnaire instruments. For example, this scale has been employed to measure subjective well-being across a variety of poor and rich country settings in the Gallup World Poll (Helliwell 2003; Diener and Tay 2015) and the UK Measuring National Well-Being programme (Evans et al. 2015). These simple quantitative measures, while imperfect, allow collection of subjective wellbeing data to be compared with material measures (e.g. income, expenditure, assets). In this study, we go further to create a poverty line in reported life satisfaction using a 10point scale and Gallup's ( 2019) Struggling category. This enables us to directly compare between subjective wellbeing and headcount ratios of poverty that are widely used and accepted in policy circles, including in Bangladesh.

\section{Ecosystem services}

When discussing the well-being of rural populations and, in particular, those dependent on natural resources for their 
income, multi-dimensional well-being is constructed in the context of the environment and its changes (Schreckenberg et al. 2018). The concept of ecosystem services takes an anthropocentric perspective on the natural environment, making explicit the links between nature and human well-being. Thus, they are defined as the benefits humans gain directly or indirectly from the natural environment (Fisher et al. 2009). Since the Millennium Ecosystem Assessment (MA 2005), which brought the idea to prominence, four broad categories of services have been utilised - provisioning (e.g. food, water), regulating (e.g. climate, water, disease regulation), cultural (e.g. spiritual, aesthetic) and supporting (e.g. primary production, soil formation). Although, various authors have modified and tried to improve on this categorisation, for example, to better account for non-material services and better disaggregate the catch-all category of cultural ecosystem services (Small et al. 2017)

The ecosystem service concept is useful as an analytical framework for understanding how natural resource dependence interacts with poverty trajectories in low-income rural settings. This body of work has shown, in general, the importance of trade-offs over time and space (e.g. Rodríguez et al. 2006; Adams et al. 2018a) and the crucial role of procedural justice in ensuring positive well-being outcomes for natural resource-dependent poor (Schreckenberg et al. 2018). An ecosystem service framework has also shown the need to disaggregate by both the type of benefit gained from the ecosystem service (e.g. subsistence or cash benefits), different user groups (e.g. men or women), as well as by value of the service (Daw et al. 2011) and demonstrated that there is variation in the sensitivity of individuals' well-being to changes in ecosystem services (Adams and Adger 2013; Daw et al. 2016).

Ecosystem services affect subjective well-being through their importance to the many life dimensions that people consider when assessing their well-being. For example, ecosystem services contribute to meeting basic human needs such as food and water security (Chaigneau et al. 2018), income and income security (Bhattamishra and Barrett 2010), the creation of safe and functional spaces in which to live (Summers et al. 2012), identity processes and the creation of meaningful spaces and practices (Adams and Adger 2013; Fish et al. 2016), as well as more directly through biophilia and the psychological benefits of proximity to nature (e.g. nature relatedness; Nisbet et al. 2011).

There is evidence on elements of subjective well-being in low-income settings (e.g. Camfield and Esposito 2014), on safety net and other social functions of ecosystem servicebased livelihoods (Fisher et al. 2014) and on the importance of land ownership and access in mediating the povertyecosystem service relationship (Hicks and Cinner 2014; Fedele et al. 2017). The contribution of this research is at the intersection of these issues: a new quantitative assessment of the relationship of ecosystem service-related income, material poverty and subjective well-being, controlling for known mediating factors. Ecosystem services are operationalised through natural resource-dependent livelihoods, drawing on a standardised list of occupations used in Household Income and Expenditure surveys in Bangladesh.

\section{Access: ecosystem bundles and social mechanisms}

Ecosystem services are not randomly distributed but are jointly produced in bundles depending on the character of the ecosystem (Raudsepp-Hearne et al. 2010; Martín-López et al. 2012). Bundles of ecosystem services form socialecological systems as they are partially the result of human activities to mediate environmental variability and manage availability (Janssen et al. 2007). The bundles cannot be defined without accounting for the social system that exists to control access and extract benefit from ecosystem processes, dictating the rules of access to resources (Walker et al. 2004). The links between values attached to particular landscapes and livelihood systems (e.g. Fagerholm et al. 2016), and the contribution of cultural ecosystem services enjoyed at the landscape scale to well-being (e.g. Bryce et al. 2016), indicates that there is merit in a social-ecological approach to subjective well-being. Here, we take the concept of bundles of ecosystem services, combined with knowledge of resource-specific access mechanisms to define social-ecological systems. Research has focused on particular resources, yet livelihoods are diverse across ecosystem services and different services have different access mechanisms.

\section{Access mechanisms}

Even when an ecosystem service is available and present in the system, this does not guarantee benefits for people. In lowincome, natural resource-dependent environments, various access mechanisms limit certain households from using ecosystem services (Hicks and Cinner 2014; Fedele et al. 2017) and a range of social processes attenuate or reinforce the benefits from ecosystem services. Social relations, through a moral economy of hierarchical structures, reciprocity and compliance with informal rules, allow those without formal property rights to ecosystem services to gain access (Wood 2003). Not all ecosystem services are available all year round, but there are seasonal cycles in the availability of certain species and in agricultural calendar (Khandker 2012). Credit is an essential means of accessing the capital required to access ecosystem benefits and to smooth over seasonal shortages; however, it often is obtained under exploitative conditions (Basu and Wong 2015). Migration is used as a livelihood risk spreading strategy to access alternative labour markets during seasonal fluctuations, as a short-term coping mechanism against shocks (Jülich 2011) and to overcome chronic livelihood insecurity (Islam and Herbeck 2013). Finally, benefits from ecosystems 
accrue up the supply chain such that those involved with direct collection can benefit least from those resources (Islam 2010).

\section{Ganges-Meghna-Brahmaputra delta in Bangladesh}

The research took place in the south and south-west coastal zone of Bangladesh. Delta ecosystems play a major role in agricultural production and food security in their regions and are sites of land use change and conflict. Deltas are highly exposed to coastal flooding and salinity intrusion (Giosan et al. 2014) and vulnerable to climate and human-driven environmental change (Renaud et al. 2013; Tessler et al. 2015). Yet, they are also attractive places for human habitation due to fertile soils, flat topography and strategic locations on the coast. Deltas are often identified as unique socialecological systems separate from other coastal areas because of their low-lying topography, high population density, fertile soils, and high levels of exposure to extreme weather, sea-level rise and infrastructural interventions such as upstream damming, coastal embankments and aquifer depletion (e.g. Brondizio et al. 2016).

However, due to their dynamic biophysical nature, deltas are also themselves composed of multiple social-ecological systems (Barbier et al. 2011). Here, we employ the categorisation of social-ecological systems detailed in Adams et al. (2016a, 2018b) to incorporate social-ecological systems into our analysis. Their definition is based on differences in bundles of ecosystem services, levels of access, the social mechanisms used to access ecosystem services, environmental degradation caused by exploiting those services and the levels of livelihood diversification across seasons and between livelihood types. Rain-fed agriculture dominates spatially, but other key systems are, irrigated agriculture, freshwater prawn aquaculture, saltwater shrimp aquaculture, eroding islands (char lands), Sundarban mangrove forest and offshore fisheries.

Bangladesh has relatively positive health outcomes, high relative literacy and has reduced mortality from natural hazards despite very low average incomes, persistent poverty and exposure to natural hazards (Chowdhury et al. 2013). However, studies in Bangladesh show low levels of reported life satisfaction and low positive affect (Asadullah and Chaudhury 2012; Mahmud and Sawada 2018). Yet, the nation has always been associated with happiness levels higher than the material conditions of its population may suggest. While the poor adapt their life expectations to the reality they face (e.g. Clark 2012), this apparent contradiction may also reflect that the Bangladeshi poor prioritise a range of life domains beyond income (Camfield et al. 2010).

\section{Methods}

\section{Operationalizing social-ecological systems}

The study focuses on the Khulna and Barisal Division in Bangladesh (Fig. 1a). This area is dominated by four land cover types: rice agriculture, aquaculture, rivers and wetlands and mangrove forest. We define seven social-ecological systems within the study area (Fig. 1b) based on the dominant livelihood regime and following the approach of Adams et al. (2016a). Four of the systems correspond with a dominant land cover type (aquaculture and agriculture); the remaining three correspond to proximity to an open access or common pool resource (the ocean or the Sundarbans forest). The Charlands represent the presence of a geographical feature within the area, that is to say, rapidly eroding and accreting riverbanks.

These social-ecological systems were identified through 75 qualitative interviews that took place in the field area between September 2012 and June 2013. Interviews were carried out with a range of inhabitants of the field area in diverse livelihoods, living in different ecological zones and under a range of material conditions. The questions focused on the relationship between ecosystem services and well-being. To access the original interview transcripts and supporting documentation, please visit Adams et al. (2016c). For further details on the systems and their specific characteristics, please see Adams et al. (2018b)).

The seven systems were assigned to administrative subunits (unions; the smallest administrative unit) using satellite imagery and geographical information system techniques. Rice agriculture and aquaculture systems could be directly assigned based on a minimum land coverage per union $(80 \%)$. Riverine, marine and Sundarbans systems were assigned based on contiguous boundaries with the associated feature. Calculations and data used to generate sampling frame can be accessed at Adams et al. (2016b).

\section{Survey design}

We collected data from 1586 households in 63 villages (households per village ranged from 21 to 27) in the coastal region of Khulna and Barisal Division in February 2014. We carried out multi-stage sampling that involved using seven social-ecological systems (described above) as the super-strata, with unions, villages and households as the subsequent strata. The sampled households are spread evenly between each social-ecological system to ensure representation from important, but less spatially dominant, systems. Systematic random sampling was used to select unions and villages, and a segment of households was listed in each village to randomly select households. The main earner of the household (whether male or female) completed the questionnaire. They were 
Fig.1 a Landsat satellite land cover image for the field area. (SES social-ecological system). b SES assigned to administrative regions (unions). Unions outlined in bold indicate survey locations
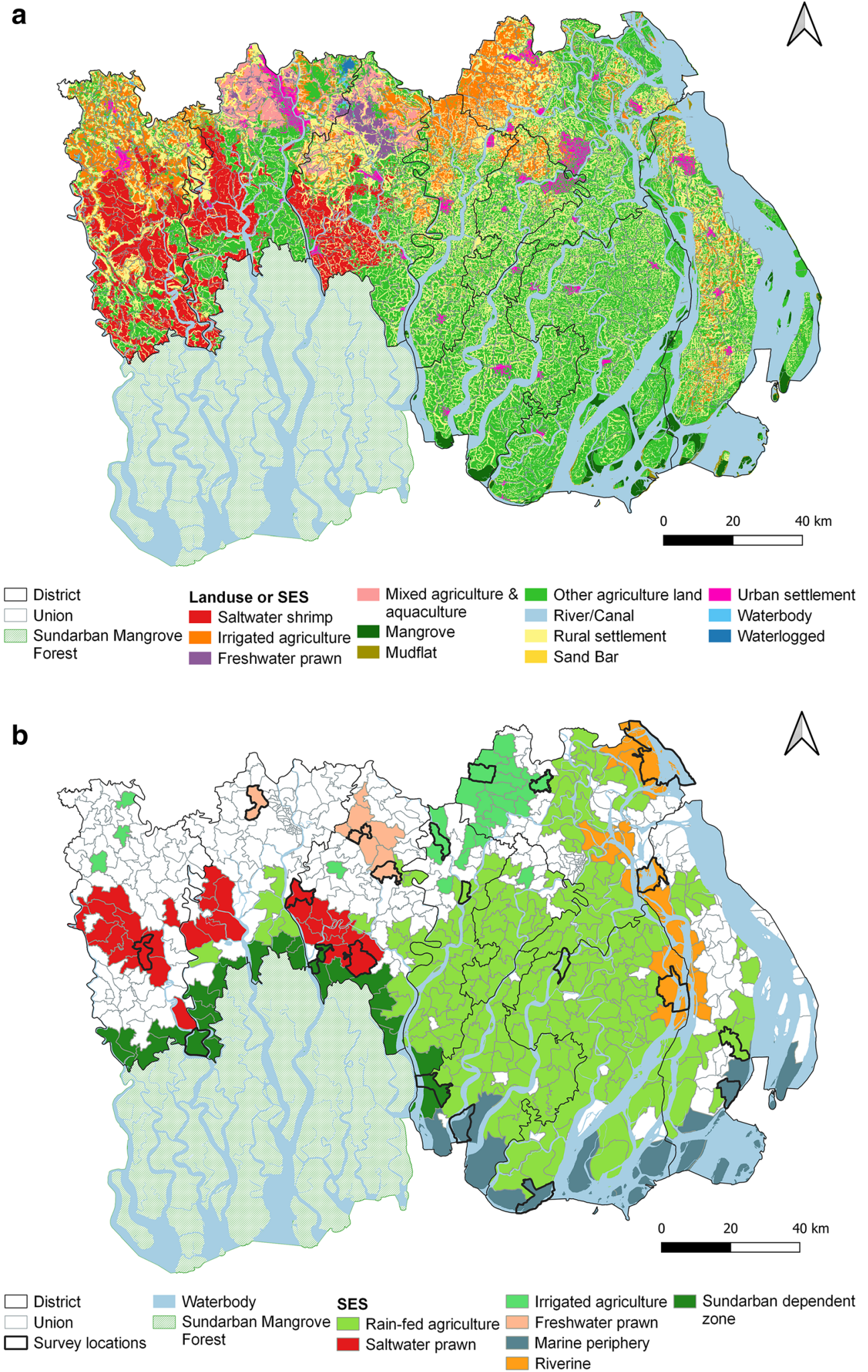

not necessarily the person the members of the household defined as the head (e.g. an older relative no longer working). The sampling protocol is fully described in Adams et al. (2016a). For access to the original dataset, questionnaire instrument and supporting documentation, please see Adams et al. (2016b).

The research protocol was reviewed and approved by the Research Review Committee and the Ethical Review 
Committee at the International Centre for Diarrhoeal Disease Research, Bangladesh. This organisation managed survey implementation. Furthermore, in order for the research to be approved by the Ethical Review Committee, all named researchers on the research protocol completed National Institutes of Health online training and ethical approval was obtained from the University of Southampton (as the lead institution of the research consortium in the UK) and the programme secretariat (Ecosystem Services for Poverty Alleviation Directorate).

\section{Variables}

\section{Material poverty}

Following the approach of the World Bank, material poverty exists when the measure of a household's material well-being is below a culturally calibrated poverty line. The material poverty line is set at the average cost of the food required to meet the nutritional requirements of a household, plus non-food requirements of a household close to the poverty line. The cost of the food and non-food items is calibrated to local prices and combined. Thus, two poverty lines are produced: an upper poverty line if household can afford the food and non-food items and a lower poverty where the household can afford the food items only. This is the approach taken by the Bangladesh Bureau of Statistics when measuring poverty through the Household Income and Expenditure Survey (Bangladesh Bureau of Statistics (BBS) 2012). The recommended calorific intake in Bangladesh is $2122 \mathrm{kcal}$. We calculated the cost of the food required to meet this value using a 10-item food basket used by the Bangladesh Household Income and Expenditure Survey.

The food basket contained rice, wheat, pulse, vegetables (aubergine, green banana, green papaya, spinach), potato, fruits (ripe banana, mango), beef, buffalo, small fish and milk. Based on this food basket, the estimated cost for a household of four (the average household size in Bangladesh) to meet their daily calorific requirements is 207 Taka, including an equivalence scale where a child's requirements are calculated as $75 \%$ of an adult. Thus, for an average household, if daily expenditure on food items is below 207 Taka, the household is considered poor. In this analysis, the calculation was weighted by household size.

\section{Reported life satisfaction}

A poverty line based on cost of basic needs was used because this is the norm in Bangladesh. In order to create a comparable threshold for reported life satisfaction, we drew on the Gallup ( 2019) category of 'Struggling'. Reported life satisfaction was measured using a 10-point global satisfaction with life scale. Following the approach of the Gallup World Poll, household heads were asked to rank their satisfaction with life at the present moment and their expected satisfaction 5 years into the future. To create a subjective well-being headcount ratio, a poverty line was created when people reported current and future expected satisfaction with life as $\leq 4$, which corresponds to the category of Struggling.

\section{Economic dependence on ecosystem services}

Economic dependence on ecosystem services is the proportion of total household income derived from provisioning and supporting ecosystem services. The proportion of income from ecosystem services is a standard method of measuring ecosystem service dependence (Yang et al. 2013), also used in the context of understanding migration from environmentally degrading regions (Ruitenbeek 1996) and household capacity to adapt to climate change (Vincent 2007). The term dependence is used to represent use or reliance on ecosystem services for income, not to suggest that households have lost agency and ecosystem services are a last resort.

The dependence measure was based on the sum of income during the 4-month recall period from agriculture, aquaculture, fishing, forest collection, livestock and poultry, homestead or farm forestry and traditional occupations involving use of primary products (furniture making from bamboo or wood, for example) as a proportion of all household income (see Table 1 in Electronic Supplementary Material). In addition, we subtracted debt repayments and added any income from remittances in the overall calculation. The recall period was based on the length of a season in Bangladesh. Note that a Pearson correlation analysis of our measure of ecosystem service dependence and total income revealed that the two were not correlated ( $r=0.03009)$, confirming that the former covariate is not serving as a proxy for total income. Subsistence is included if the interviewee incorporated it into their selfassessment of income; however, the self-assessment did not specifically ask about food as gift/assistance and as such this may have been omitted. We created a categorical variable for the dependence to take into account the fact that those with zero or $100 \%$ contribution of ecosystem services could be both poor and well-off, as outlined above, as well as to investigate proportions in between these extremes. Thus, four categories were created: $0 \%, 1-49 \%, 50-99 \%$ and $100 \%$.

\section{Social mechanisms}

We examined five enablers and barriers to poverty alleviation, namely land ownership, sharecropping, possession of a loan, receiving remittances and experience of an environmental or social shock. Households were classified into three categories of land ownership: functionally landless $(<0.2$ acres), small landowners (0.2-2.5 acres) and larger landowners $(>2.5$ acres). If the household had taken land to sharecrop in the past 
4 months, it was classed as a sharecropping household. Since prevalence of households that had taken land in this way was low, we did not further subdivide the variable into area of land. There was no significant correlation between land ownership and use of sharecropping. Households were classified as possessing a loan or not. Note that absolute value of debt ascribable to each household could not be included as a covariate because these values were also included in the material poverty calculation.

Given that prevalence of households with a migrant sending remittances was low, remittances were treated as a dichotomous variable in the model (receiving remittances or not) and not further subdivided into value or frequency. If the household currently had a household member outside of the village who was sending remittances, or if in the past 4 months (the recall period of the survey), someone from the household had migrated and remitted (but now returned) the household was classed as a remittance household.

We elicited whether households had experienced a shock in the past 4 months, distinguishing between shocks with an environmental root and those with a personal or social root. The questionnaire asked: "Has any member of the household faced any of the following situations during the past four months?" and listed various shocks present in the area. Environmental shocks listed included drought, floods, cyclones, river erosion, waterlogging, crop disease, increase in price of agricultural inputs or decrease in price of agricultural produce. Social or household shocks listed included: job loss, accident or illness of main earner, accident or illness of other household members, death of household members, conflict with neighbours, theft of assets and labour strikes.

\section{Demographics}

Demographic characteristics examined included gender, education, household size and household dependency ratio. Note that in the model assessing reported life satisfaction, household wealth was controlled for through adding an asset index as a covariate. The asset index was derived through principal component analysis using the methodology described in Filmer and Pritchett (2001). It was then categorised into wealth quintiles. Household dependency ratio was calculated using the following equation: $\left(\left(P_{0}+P_{2}\right) / P_{1}\right) \times 100$, where $P_{0}$ is the number of individuals in the household aged $0-14$ years, $P_{1}$ is the number of individuals in the household aged 1564 years, and $P_{2}$ is the number of individuals aged 65 years or over.

\section{Data analysis}

To examine the relationship between ecosystem service dependence and poverty, we employed logistic random intercept models to account for the hierarchical structure of the data and potential unit dependence. With $i$ denoting households and $j$ denoting villages, the equation for a two-level logistic multilevel model with a random intercept fitted at the village level is given as

$\operatorname{logit}\left(\frac{\pi_{i j}}{1-\pi_{i j}}\right)=\beta_{1} x_{i j}+\beta_{2} x_{i j}+\ldots+\beta_{n} x_{i j}$

$\beta_{o j}=\beta_{j}+u_{j}$

where $\beta_{0 j}$ is the random intercept at village, $\beta_{1} x_{i j}$ is the logit coefficient at level of households, and $u_{j}$ is the variance of the random intercept fitted at village level. $u_{j}$ follows a normal distribution with a mean of zero and variance equal to $\sigma_{u}^{2}$.

Model selection was determined as follows. First, bivariate analysis between the outcome variables and individual covariates were conducted before single-level logistic models were fitted to explore which covariates were statistically significantly associated with material poverty and reported life satisfaction, respectively. Caterpillar plots were used to assess the variation of residuals at the village level (Supplementary figures 1 and 2). In the logistic random intercept models, Wald tests were used to assess the statistical significance of random parameter variance and fixed effect coefficients. The aim of the modelling process was to retain the most parsimonious models assessed by goodness of fit statistics. As a result, covariates that were not significant were excluded from the final models. Since residuals at the village levels follow a normal distribution, linearity, constant variance and unit independence assumptions were explored through plots. The results are presented in Supplementary figures 3 and 4. All analyses were conducted in Stata.

\section{Results}

Our results suggest that economic dependence on ecosystem services is significantly associated with material poverty and reported life satisfaction. In general, a greater contribution of ecosystem service-related income to the livelihood mix is related to a decreased likelihood of material poverty, the relationship with reported life satisfaction is present but weaker.

Further, we found that both material poverty and reported life satisfaction were predicted by covariates related to demographics and environmental shocks, but the magnitude and direction of the effect differs by poverty dimension. The social mechanisms (enablers and barriers to poverty alleviation) were not significantly related to poverty outcomes in the model for either dimension of poverty apart from remittances. However, the type of social-ecological system people resided in was significantly associated with reported life satisfaction. 


\section{Ecosystem service dependence and social-ecological system}

\section{Material poverty}

Our results suggest that the likelihood of being under the poverty line decreases with increasing economic dependence on ecosystem services. Compared with a household with no contribution of ecosystem service-based livelihoods to its income, a household with up to half of its income from ecosystem service-based livelihoods was $33 \%$ less likely to be materially poor; a household with over $50 \%$ but less than $100 \%$ of its income from ecosystem service-based livelihoods was $37 \%$ less likely to be materially poor; and a household with $100 \%$ of its income from ecosystem service-based livelihoods was $40 \%$ less likely to be materially poor. There was no significant relationship between social-ecological system and material poverty in the model (see Table 1 and Fig. 2).

\section{Low reported life satisfaction}

Our results suggest that the likelihood of reporting low life satisfaction decreases with increasing economic dependence on ecosystem services, controlling for material wealth. Compared with a household with no contribution of ecosystem service-based livelihoods to its income, a household with up to half of its income from ecosystem service-based livelihoods was $43 \%$ less likely to report low life satisfaction and a household with over half but less than $100 \%$ of its income from ecosystem service-based livelihoods was $38 \%$ less likely to report low life satisfaction. There was no significant relationship between low reported life satisfaction and $100 \%$ of a household's income originating from ecosystem service-based livelihoods (see Table 1 and Fig. 3).

In contrast to material poverty, the social-ecological system in which the household was situated is significantly associated with reporting low life satisfaction. That is to say, people are more satisfied in some social-ecological systems than others. We used the saltwater shrimp category as our reference category because it is the most altered and degraded of the socialecological systems. The likelihood of reporting low life satisfaction was lower in all other systems compared with this one. The likelihood of being satisfied is highest in the riverine (91\% less likely to report low life satisfaction) and marine (82\% less likely) systems and lowest in freshwater prawn (44\% less likely) and forest periphery (53\% less likely) systems compared with the saltwater shrimp system. The likelihood of reporting low life satisfaction compared with living in the saltwater shrimp system fell somewhere between for the agricultural systems (irrigated $74 \%$ less likely; rainfed $71 \%$ less likely). Thus, our results show the importance of the condition of the social-ecological system in which a person lives for generating life satisfaction.

\section{Demographics}

Both material poverty and reported life satisfaction were significantly related to demographic characteristics (Table 1). The influence of education was consistent across both poverty dimensions, with the probability of being materially poor or dissatisfied with life being significantly less likely if the respondent had secondary school education. Household size and dependency ratio showed no significant relationship with reported life satisfaction but were significantly and positively related to material poverty; for example, households with five or more members are just under three times as likely to be materially poor than households with fewer than five members. Gender is not significantly related to either dimension of poverty. Material wealth (included as a control in the life satisfaction model to isolate the effect of economic dependence on ecosystem services) is significantly related to life satisfaction, with the model suggesting an $81 \%$ decrease in the odds of being subjectively poor if a household was in the top wealth quintile compared with being in the bottom wealth quintile. Thus, our results support the importance of material conditions for generating life satisfaction (see Table 1 and Figs. 2 and 3).

\section{Social mechanisms mediating access to ecosystem services}

Of the social mechanisms that limit access included in the model (namely land ownership, sharecropping, possession of a loan, receiving remittances and experience of an environmental or social shock) only land ownership, experiencing an environmental shock and remittances showed a significant relationship with the poverty variables. Compared with being landless or functionally landless, owning some land decreased the probability of material poverty by $54 \%$ and significant landholdings decreased the probability of material poverty by $81 \%$. Experience of an environmental shock in the previous 4 months reduced the chances of a household experiencing material poverty by $25 \%$ compared with a household that had not experienced a shock.

Neither of these relationships was significant for reported life satisfaction. However, a household that received remittances was $48 \%$ less likely to report low life satisfaction than one without them (see Table 1 and Figs. 2 and 3). Thus, our results support the importance of landholdings for keeping people above the poverty line, that better-off households potentially have more to lose in absolute terms in extreme events (although less in relative terms) and that having a family member working in an alternative labour market has the potential to increase life satisfaction. 
Table 1 Odds ratios describing the relationship of material poverty and reported life satisfaction with economic ecosystem service dependence, social-ecological system and various household-scale covariates (except education, which was for the household head). Gender and experience of a household shock (e.g. job loss or illness of a main income earner) were not significantly related to either material poverty or low life satisfaction

\begin{tabular}{|c|c|c|c|}
\hline & \multirow[b]{2}{*}{ Covariate/parameter } & \multicolumn{2}{|l|}{ Poverty dimension } \\
\hline & & Material poverty & Low life satisfaction \\
\hline & Intercept & 1.003 & 7.625 \\
\hline \multirow[t]{5}{*}{ Economic ecosystem service (ES) dependence } & Income $\%$ from ecosystem services & & \\
\hline & $0 \%$ & 1.000 & 1.000 \\
\hline & $1-49 \%$ & $0.668^{* *}$ & $0.566 * * *$ \\
\hline & $50-99 \%$ & $0.627 * *$ & $0.616^{*}$ \\
\hline & $100 \%$ & $0.596^{*}$ & 0.692 \\
\hline \multirow[t]{6}{*}{ Social-ecological system (SES) } & Saltwater shrimp & ns & 1.000 \\
\hline & Mangrove forest periphery & ns & $0.469^{*}$ \\
\hline & Riverine & ns & $0.086 * * *$ \\
\hline & Rain-fed agriculture & ns & $0.290 * * *$ \\
\hline & Freshwater prawn & ns & $0.357 * *$ \\
\hline & Irrigated agriculture & ns & $0.262 * * *$ \\
\hline ES dependence $\times$ SES & Marine periphery & ns & $0.180 * * *$ \\
\hline \multicolumn{4}{|l|}{ Demographics } \\
\hline \multirow[t]{3}{*}{ Education } & No education & 1.000 & 1.000 \\
\hline & Primary school & 0.956 & 0.773 \\
\hline & Secondary school & $0.468 * * *$ & $0.395 * * *$ \\
\hline Household size & $\begin{array}{l}<4 \text { members } \\
5+\text { members }\end{array}$ & $\begin{array}{l}1.000 \\
2.826^{* * * *}\end{array}$ & ns \\
\hline Household dependence ratio & $0-25 \%$ & 1.000 & \\
\hline \multirow[t]{4}{*}{ Dependency ratio } & $\begin{array}{l}0-25 \% \\
26-50 \%\end{array}$ & $\begin{array}{l}1.000 \\
1.038\end{array}$ & ns \\
\hline & $51-75 \%$ & 0.984 & \\
\hline & $76-100 \%$ & $1.723 * *$ & \\
\hline & $100+\%$ & 1.166 & \\
\hline \multicolumn{4}{|l|}{ Enablers and barriers to poverty alleviation } \\
\hline \multirow[t]{5}{*}{ Wealth } & Poorest & na & 1.000 \\
\hline & $\begin{array}{l}\text { Poor } \\
\text { Medium }\end{array}$ & & $0.520 * * *$ \\
\hline & Richer & & $0.308 * * *$ \\
\hline & Richest & & $0.225 * * *$ \\
\hline & & & $0.094 * * *$ \\
\hline \multirow[t]{3}{*}{ Land ownership } & No land/homestead only & 1.000 & ns \\
\hline & Small land owner & $0.456^{* * *}$ & \\
\hline & Medium/large land owner & $0.187 * * *$ & \\
\hline \multirow[t]{2}{*}{ Environmental shock } & No shock experienced & 1.000 & ns \\
\hline & Shock experienced & $0.745^{*}$ & \\
\hline \multirow[t]{2}{*}{ Remittances } & No contribution & $\mathrm{ns}$ & 1.000 \\
\hline & Some contribution & & $0.524 * * *$ \\
\hline \multicolumn{4}{|l|}{ Random effects } \\
\hline \multirow[t]{2}{*}{ Random intercept } & Variance & 0.300 & 0.279 \\
\hline & Standard error & 0.095 & 0.109 \\
\hline
\end{tabular}

Note that the landholder categories were merged for the subjective poverty model

$n s$ non-significant, $n a$ not applicable

${ }^{*} p<0.05 ; * *<0.01 ; * * *<0.001$ 
Fig. 2 Odds ratios for material poverty against the reference category ( 1 on the $x$-axis). The likelihood of being under the poverty line decreases with increasing economic dependence on ecosystem services. ES ecosystem services, $\mathrm{HH}$ household

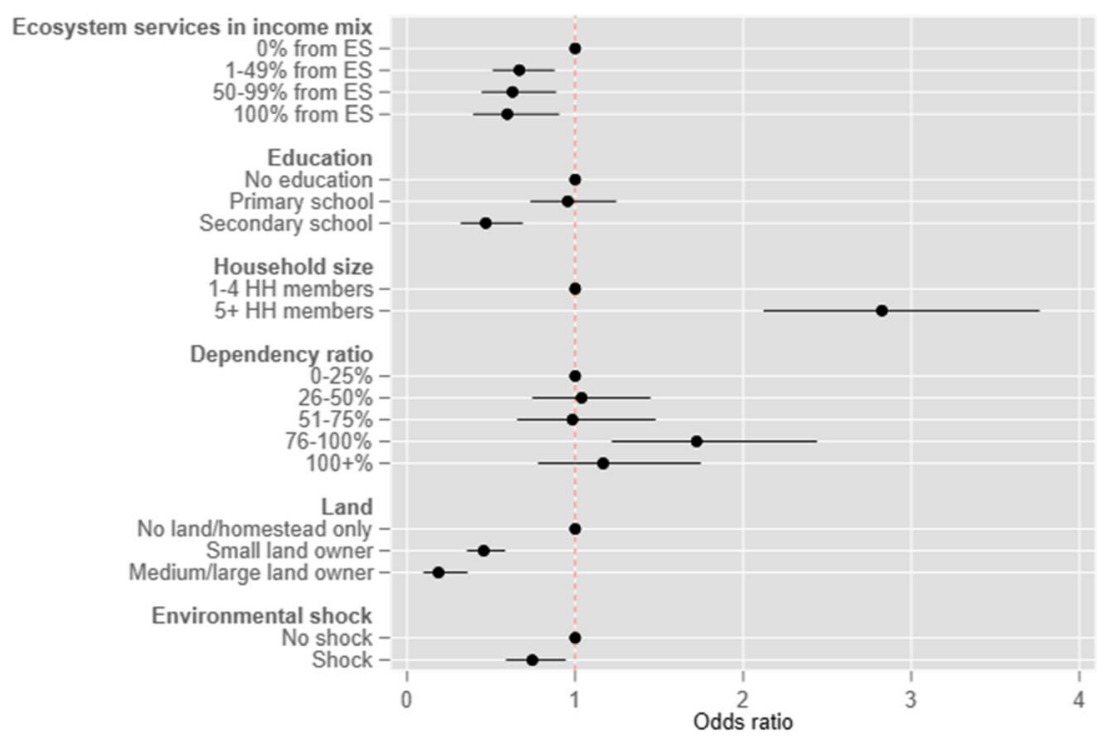

\section{Discussion}

In this paper, we investigated how different contributions of ecosystem services to the livelihood mix are associated with well-being. We examined two aspects of well-being: material poverty (based on ability to meet cost of basic needs) and reported life satisfaction (current and future reported life satisfaction of household head below 4 on a 10-point scale) in the south-west coastal zone of Bangladesh. We controlled for availability of different bundles of ecosystem services by stratifying by social-ecological system and included social mechanisms that determine access and spread risk. The research represents a novel contribution to poverty research in three ways: accounting for nature's contribution to income in traditional poverty accounting, creating a subjective well-being comparator to head count poverty ratios and stratifying poverty analysis by social-ecological system to show how well-being varies spatially in diverse environments.

\section{Do natural resources cause poverty or does poverty cause reliance on ecosystem services?}

Our results show that households with no contribution of ecosystem services to their household livelihood mix are more likely to be both poor and have a household head who is dissatisfied with life. A larger proportion of ecosystem serviced-based livelihoods in the livelihood mix further reduce the likelihood of poverty compared with no contribution of ecosystem services. Thus, the results support those that show well-being in natural resource-dependent communities relates to access to natural resources (e.g. Hicks and Cinner 2014).The relationship holds for reported life satisfaction of
Fig. 3 Odds ratios for low life satisfaction against the reference category ( 1 on the $x$-axis). The likelihood of reporting low life satisfaction decreases with increasing economic dependence on ecosystem services, controlling for material wealth. Social-ecological system is significantly associated with reporting low life satisfaction. ES ecosystem services, $\mathrm{HH}$ household

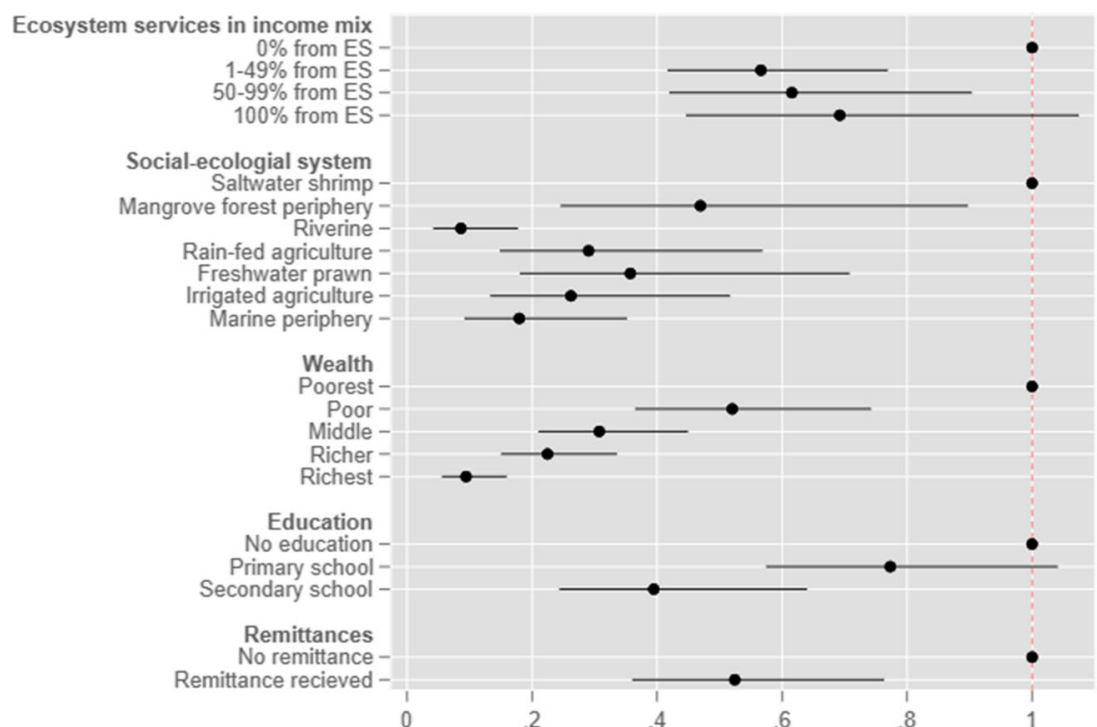


the household head. However, we were not able to investigate intra-household differences in reported life satisfaction.

Thus, while household diversification is a key coping strategy in times of a stress, especially in agricultural low seasons (Ellis 1998), our results show that those who are unable to maintain or gain access to ecosystem-based livelihoods suffer, regardless of diversification into off-farm income sources. Thus, they highlight the limits to diversification when there is a lack of sophisticated off-farm jobs, as is the case in Bangladesh (Rahman et al. 2013) and support research that shows the success of livelihood diversification as a strategy depends on the initial assets and capabilities of the household (Goulden et al. 2013). Households registering as having little or no income from ecosystem services could also represent a farmer not having yet harvested. Thus, the results may reflect the lack of diversification of farmers and/or ability to save or transfer credit order to smooth income over time (Khandker 2012). Diversification through migration to alternative labour markets is also not used in a detectable way to sustain rural lifestyles, contrasting with findings in other remote rural settings (e.g. Nepal; see Blaikie et al. 2002). The results also reflect the crucial role of land ownership in providing basic levels of security. In Bangladesh, land is historically unevenly distributed (Paprocki 2015), and ownership has been further concentrated as families sell land as a coping strategy during times of crisis.

The relationship between our covariates and material and subjective well-being sometimes ran counter to established knowledge on the causes of poverty. For example, idiosyncratic (e.g. death or illness of a main income earner) and covariate (e.g. widespread flooding) shocks are known reasons for households to fall into poverty; indeed, this has been shown in Bangladesh (Rahman et al. 2013). Yet, our results show no association between material poverty and reporting experience of social/economic shocks in the previous 4 months. Further, reporting experience of an environmental shock in the previous 4 months decreases the odds of material poverty. Explanations could lie in the fact that people who are more likely to be impacted by environmental shocks such as floods or droughts are those with higher access to, and/or ownership of, ecosystem services (e.g. land). Those with more assets, while more able to cope, are more exposed and lose more in absolute terms. Further, this result could be a result of aggregating responses over the 4-month recall period, such that income shocks had already been smoothed over. Furthermore, we are measuring income not assets, and poverty may be reflected in another dimension of wealth such as assets (Sultana and Rayhan 2012).

\section{Well-being from ecosystem services in environmentally degraded social-ecological systems}

Bangladesh has suffered loss of ecosystem services as a result of the intensive monoculture agriculture and aquaculture (Houssain et al. 2016). Not all social-ecological systems on the delta are equally degraded with agriculture and aquaculture operating at different degrees of intensity and exclusion of other services (Adams et al. 2018a; Zhang et al. 2015). For example, unlike in saltwater shrimp systems, freshwater prawn systems are able to co-exist with agriculture, cattle and home gardens.

Our results show that the negative relationship between percentage ecosystem service-related livelihoods and material poverty does not vary with social-ecological system, controlling for material wealth and differences in access mechanisms; the benefits of agricultural intensification have not advantaged one system over the other, despite environmental degradation. However, there are differences in absolute levels of reported life satisfaction between social-ecological system. The probability of being dissatisfied is lower in all other socialecological systems compared with the saltwater shrimp social-ecological system, with the probability of dissatisfaction lowest in the riverine social-ecological system. Dissatisfaction was most likely in the most environmentally degraded, but economically important, social-ecological system; saltwater shrimp represented $81 \%$ of the total export value in Bangladesh in 2012/2013 (Rashid et al. 2019).

Saltwater shrimp aquaculture has degraded diverse ecosystems, undermining subsistence farming and food security (Paprocki and Cons 2014) and generating environmental issues (Afroz and Alam 2013) that could cause low reported life satisfaction through various mechanisms. Higher perception of environmental change has been linked with lower levels of subjective well-being (Alfonso et al. 2017) caused by biophilia and nature connectedness (Nisbet et al. 2011). Perception of environmental degradation was tested as a variable in the model but was not found to be significant. The change in land use has altered the moral economy of the region: absentee landlords that would have traditionally provided security to the poorest are absent (Ito 2002) and a decrease in agricultural jobs has dispaced local residents (Paprocki and Cons 2014). Low levels of life satisfaction could also be associated with a change in the landscape impacting meaningful activities and spaces (Fish et al. 2016) eroding the cultural, landscape and identity values of the environment. Cultural ecosystem services are not items in the environment, but represent symbolic or aesthetic meaning (Kirchhoff 2012) ascribed to physical elements of the environment. They are often more associated with landscape 
values, or practices and interactions that take place within environments (Tengberg et al. 2012; Fish et al. 2016).

The probability of low reported life satisfaction is lowest in the riverine social-ecological system. This could be explained by assigning adaptable characteristics to a population that has been forced to cope with very dynamic geomorphology (Sarker et al. 2003) through high levels of social capital (Lein 2009). However, in general, the lives of char dwellers in the riverine system are characterised by extreme precarity in land tenure, often living on government (khas) land, with few livelihood assets and a high dependence on money lenders (Paul and Islam 2015) as they are constantly displaced by erosion. Further, the geographic remoteness of char areas leads to a lack of engagement with local government services and a lack of knowledge of rights (Paul and Islam 2015). Thus, high subjective well-being may be the result of a marginal existence causing lack of awareness of a deficit in services and rights.

Our results are relevant to ongoing work that links environmental sustainability to human health in a more a holistic manner - such as the 'One Health' framework that draws together individual, population and ecosystem health (Lerner and Berg 2015), since we show the association between ecosystem health and subjective well-being. Our results also speak to the concept of Nature's Contribution to People, which has emerged from the Intergovernmental SciencePolicy Platform on Biodiversity and Ecosystem Services (IPBES) Global Assessment on Biodiversity and Ecosystem Services (Díaz et al. 2018). This concept focuses on cultural and local understandings of ecosystem services; our results are relevant since we demonstrate the importance of different social-ecological systems (landscapes) to life satisfaction, where we observed no differences in material conditions, and as such show the importance of nature's non-material contributions to people.

\section{Conclusion}

This study investigates associations between ecosystem services and poverty alleviation in a diverse deltaic environment, highly degraded by intensive agriculture and aquaculture. This area in Bangladesh is dominated by monoculture cash crops, historical unequal land distribution (Paprocki 2015) and high-end off-farm livelihood opportunities are few (Rahman et al. 2013). By explicitly incorporating provisioning ecosystem services into our analysis of poverty, and creating subjective well-being comparators to standard headcount poverty ratios, we have highlighted the importance of nature for diverse well-being outcomes of those living in the delta coast of Bangladesh.

Trade-offs over space, time and beneficiaries are inherent in ecosystems (Rodríguez et al. 2006; Daw et al. 2011;
Hossain et al. 2016), and others have highlighted the tension between poverty reduction at the national level through export-oriented production, and environmental and social sustainability at the local level (Hossain et al. 2016; Paprocki and Cons 2014). Here, we highlight the negative implications of over-exploitation of ecosystem services for subjective wellbeing. While development of the aquaculture sector has been found to modestly increase the material well-being of those in the lowest wealth quintile, and as such can be considered propoor (Rashid et al. 2019), these benefits are difficult to ascribe to those directly affected by the negative environmental and social impacts of the shrimp aquaculture. Our results show that the residents of the area do not consider themselves to be living well, demonstrating a trade-off between national development strategies represented by shrimp export and the life satisfaction of those most affected.

Acknowledgements We express our gratitude to the households who gave their time to take part in the survey and Tauhida Nasrin and the team of enumerators who ensured high-quality data collection in adverse conditions. We acknowledge input from ESPA Deltas members Munsur Rahman, Rezaur Rahman, Mashfiqus Salehin, Munir Ahmed, Hamidul Huq, Robert Nicholls, Craig Hutton, Fiifi Amoako Johnson and Mahin Al Nahian. We thank Viviane Dib for generating Fig. 1, Janet Fisher and Christina Hicks for comments on earlier drafts and those who gave feedback on presentations of these results at conferences and workshops. This version remains our own responsibility.

Funding information The study is financially supported by the UK Natural Environment Research Council, Economic and Social Research Council and Department for International Development for Assessing Health, Livelihoods, Ecosystem Services And Poverty Alleviation In Populous Deltas (ESPA Deltas; NERC grant no. is NE/J000892/1) under the Ecosystem Services for Poverty Alleviation (ESPA) programme.

Open Access This article is licensed under a Creative Commons Attribution 4.0 International License, which permits use, sharing, adaptation, distribution and reproduction in any medium or format, as long as you give appropriate credit to the original author(s) and the source, provide a link to the Creative Commons licence, and indicate if changes were made. The images or other third party material in this article are included in the article's Creative Commons licence, unless indicated otherwise in a credit line to the material. If material is not included in the article's Creative Commons licence and your intended use is not permitted by statutory regulation or exceeds the permitted use, you will need to obtain permission directly from the copyright holder. To view a copy of this licence, visit http://creativecommons.org/licenses/by/4.0/.

\section{References}

Adams H, Adger WN (2013) The contribution of ecosystem services to place utility as a determinant of migration decision-making. Environ Res Lett 8(1):015006. https://doi.org/10.1088/1748-9326/8/1/ 015006

Adams H, Adger WN(2016) Mechanisms and dynamics of wellbeingecosystem service links in the southwest coastal zone of 
Bangladesh. [Data Collection]. Colchester, Essex: UK Data Archive. https://doi.org/10.5255/UKDA-SN-852356

Adams H, Adger WN, Ahmad S, Ahmed A, Begum D, Lázár AN, Matthews Z, Rahman MM, Streatfield PK (2016a) Spatial and temporal dynamics of multidimensional well-being, livelihoods and ecosystem services in coastal Bangladesh. Sci Data 3:160094160011. https://doi.org/10.1038/sdata.2016.94

Adams H, Adger WN, Ahmad S, Ahmed A, Begum D, Matthews Z, Rahman MM, Streatfield PK (2016b) Spatial and temporal dynamics of multidimensional well-being, livelihoods and ecosystem services in coastal Bangladesh. [Data Collection]. Colchester, Essex: UK Data Archive. https://doi.org/10.5255/UKDA-SN-852179

Adams H, Adger WN (2016c) Mechanisms and dynamics of wellbeingecosystem service links in the southwest coastal zone of Bangladesh. [Data Collection]. Colchester, Essex: UK Data Archive. https://doi.org/10.5255/UKDA-SN-852356

Adams H, Adger WN, Nicholls RJ (2018a) Ecosystem services linked to livelihoods and well-being in the Ganges-Brahmaputra-Meghna Delta. In: Nicholls RJ, Hutton CW, Adger WN, Hanson SE, Rahman MM, Salehin M (eds) Ecosystem services for well-being in deltas. Palgrave Macmillan, Cham. https://doi.org/10.1007/9783-319-71093-8 2

Adams H, Adger WN, Ahmed M, Huq H, Rahman R, Salehin M (2018b) Defining social-ecological systems in south-west Bangladesh. In: Nicholls RJ, Hutton CW, Adger WN, Hanson SE, Rahman MM, Salehin M (eds) Ecosystem Services for Well-Being in Deltas. Palgrave Macmillan, Cham. https://doi.org/10.1007/978-3-31971093-8 22

Afroz T, Alam S (2013) Sustainable shrimp farming in Bangladesh: a quest for an integrated coastal zone management. Ocean Coast Manag 71:275-283. https://doi.org/10.1016/j.ocecoaman.2012.10. 006

Alfonso A, Zorondo-Rodríguez F, Simonetti JA (2017) Perceived changes in environmental degradation and loss of ecosystem services, and their implications in human well-being. Int J Sust Dev World 24(6): 561-574. https://doi.org/10.1080/13504509.2016.1255674

Alkire S, Foster J (2011) Counting and multidimensional poverty measurement. J Public Econ 95(7-8):476-487. https://doi.org/10.1016/ j.jpubeco.2010.11.006

Asadullah MN, Chaudhury N (2012) Subjective well-being and relative poverty in rural Bangladesh. J Econ Psychol 33(5):940-950. https:// doi.org/10.1016/j.joep.2012.05.003

Bangladesh Bureau of Statistics (BBS) (2012) Bangladesh household income and expenditure survey 2010: key findings and results. BBS and World Bank, Dhaka

Barbier EB, Hacker SD, Kennedy C, Koch EW, Stier AC, Silliman BR (2011) The value of estuarine and coastal ecosystem services. Ecol Monogr 81(2):169-193. https://doi.org/10.1890/10-1510.1

Basu K, Wong M (2015) Evaluating seasonal food storage and credit programs in east Indonesia. J Dev Econ 115:200-216. https://doi. org/10.1016/j.jdeveco.2015.02.001

Bebbington A (2000) Reencountering development: livelihood transitions and place transformations in the Andes. Ann Assoc Am Geogr 90(3):495-520. https://doi.org/10.1111/0004-5608.00206

Béné C (2003) When fishery rhymes with poverty: a first step beyond the old paradigm on poverty in small-scale fisheries. World Dev 31(6): 949-975. https://doi.org/10.1016/S0305-750X(03)00045-7

Bhattamishra R, Barrett CB (2010) Community-based risk management arrangements: a review. World Dev 38(7):923-932. https://doi.org/ 10.1016/j.worlddev.2009.12.017

Blaikie P, Cameron J, Seddon D (2002) Understanding 20 years of change in West-Central Nepal: continuity and change in lives and ideas. World Dev 30(7):1255-1270. https://doi.org/10.1016/S0305750X(02)00031-1

Brondizio ES, Vogt ND, Mansur AV, Anthony EJ, Costa S, Hetrick S (2016) A conceptual framework for analyzing deltas as coupled social-ecological systems: an example from the Amazon River Delta. Sustain Sci 11(4):591-609. https://doi.org/10.1007/s11625016-0368-2

Bryce R, Irvine KN, Church A, Fish R, Ranger S, Kenter JO (2016) Subjective well-being indicators for large-scale assessment of cultural ecosystem services. Ecosyst Serv 21:258-269. https://doi.org/ 10.1016/j.ecoser.2016.07.015

Camfield L, Esposito L (2014) A cross-country analysis of perceived economic status and life satisfaction in high-and low-income countries. World Dev 59:212-223. https://doi.org/10.1016/j.worlddev. 2014.01.018

Camfield L, Guillen-Royo M, Velazco J (2010) Does needs satisfaction matter for psychological and subjective wellbeing in developing countries: a mixed-methods illustration from Bangladesh and Thailand. J Happiness Stud 11(4):497-516. https://doi.org/10. 1007/s10902-009-9154-5

Carter MR, Barrett CB (2006) The economics of poverty traps and persistent poverty: an asset-based approach. J Dev Stud 42(2):178-199. https://doi.org/10.1080/00220380500405261

Chaigneau T, Coulthard S, Brown K, Daw TM, Schulte-Herbrüggen B (2018) Incorporating basic needs to reconcile poverty and ecosystem services. Conserv Biol 33(3):655-664. https://doi.org/10.1111/ cobi.13209

Chowdhury AMR, Bhuiya A, Chowdhury ME, Rasheed S et al (2013) The Bangladesh paradox: exceptional health achievement despite economic poverty. Lancet 382(9906):1734-1745. https://doi.org/ $10.1016 / \mathrm{S} 0140-6736(13) 62148-0$

Clark DA (2012) Adaptation, poverty and development: the dynamics of subjective well-being. Palgrave Macmillan, London. https://doi.org/ $10.1057 / 9781137002778$

Cojocaru A (2016) Does relative deprivation matter in developing countries: evidence from six transition economies. Soc Indic Res 125(3): 735-756. https://doi.org/10.1007/s11205-015-0864-2

Daw T, Brown K, Rosendo S, Pomeroy R (2011) Applying the ecosystem services concept to poverty alleviation: the need to disaggregate human well-being. Environ Conserv 38(04):370-379. https://doi. org/10.1017/S0376892911000506

Daw T, Christina C. Hicks, Brown K, Chaigneau T, Januchowski-Hartley FA, Cheung WL, Rosendo S, Crona B, Coulthard S, Sandbrook C, Perry C, Bandeira S, Muthiga NA, Schulte-Herbrüggen B, Bosire J, McClanahan TR (2016) Elasticity in ecosystem services: exploring the variable relationship between ecosystems and human well-being. Ecol Soc 21(2):11

Díaz S, Pascual U, Stenseke M, Martín-López B, Watson RT, Molnár Z, Hill R, Chan KMA, Baste IA, Brauman KA, Polasky S, Church A, Lonsdale M, Larigauderie A, Leadley PW, van Oudenhoven A, van der Plaat F, Schröter M, Lavorel S, Aumeeruddy-Thomas Y, Bukvareva E, Davies K, Demissew S, Erpul G, Failler P, Guerra CA, Hewitt CL, Keune H, Lindley S, Shirayama Y (2018) Assessing nature's contributions to people. Science 359(6373): 270-272. https://doi.org/10.1126/science.aap8826

Diener E, Tay L (2015) Subjective well-being and human welfare around the world as reflected in the Gallup World Poll. Int J Psychol (502): 135-149. https://doi.org/10.1002/ijop.12136

Diener E, Inglehart R, Tay L (2013) Theory and validity of life satisfaction scales. Soc Indic Res 112(3):497-527. https://doi.org/10.1007/ s11205-012-0076-y

Diener E, Heintzelman SJ, Kushlev K, Tay L, Wirtz D et al (2017) Findings all psychologists should know from the new science on subjective well-being. Can Psychol 58(2):87-104. https://doi.org/ $10.1037 /$ cap0000063

Ellis F (1998) Household strategies and rural livelihood diversification. J Dev Stud 35(1):1-38. https://doi.org/10.1080/00220389808422553

Evans J, Macrory I, Randall C (2015) Measuring national well-being: life in the UK, 2015. Office for National Statistics, London 
Fagerholm N, Oteros-Rozas E, Raymond CM, Torralba M, Moreno G, Plieninger T (2016) Assessing linkages between ecosystem services, land-use and well-being in an agroforestry landscape using public participation GIS. Appl Geogr 74:30-46. https://doi.org/10.1016/j. apgeog.2016.06.007

Fedele G, Locatelli B, Djoudi H (2017) Mechanisms mediating the contribution of ecosystem services to human well-being and resilience. Ecosyst Serv 28:43-54. https://doi.org/10.1016/j.ecoser.2017.09. 011

Filmer D, Pritchett LH (2001) Estimating wealth effects without expenditure data - or tears: an application to educational enrolments in states of India. Demography 38(1):115-132. https://doi.org/10. 1353/dem.2001.0003

Fish R, Church A, Winter M (2016) Conceptualising cultural ecosystem services: a novel framework for research and critical engagement. Ecosyst Serv 21:208-217. https://doi.org/10.1016/j.ecoser.2016.09. 002

Fisher B, Turner RK, Morling P (2009) Defining and classifying ecosystem services for decision making. Ecol Econ 68(3):643-653. https:// doi.org/10.1016/j.ecolecon.2008.09.014

Fisher JA, Patenaude G, Kalpana G, Lewis K, Meir P, Pinho M, Rounsevell MDA, Williams M (2014) Understanding the relationships between ecosystem services and poverty alleviation: a conceptual framework. Ecosyst Serv 7:34-45. https://doi.org/10.1016/j. ecoser.2013.08.002

Gallup (2019) Understanding How Gallup Uses the Cantril Scale. https:// news.gallup.com/poll/122453/understanding-gallup-uses-cantrilscale.aspx. Accessed 4 December 2019

Giosan L, Syvitski J, Constantinescu S, Day J (2014) Climate change: protect the world's deltas. Nature 516:31-33. https://doi.org/10. $1038 / 516031 \mathrm{a}$

Gough I, McGregor JA (2007) Wellbeing in developing countries: from theory to research. Cambridge University Press, Cambridge

Goulden MC, Adger WN, Allison EH, Conway D (2013) Limits to resilience from livelihood diversification and social capital in lake social-ecological systems. Ann Assoc Am Geogr 103(4):906-924. https://doi.org/10.1080/00045608.2013.765771

Hamann M, Biggs R, Reyers B (2015) Mapping social-ecological systems: identifying 'green-loop' and 'red-loop' dynamics based on characteristic bundles of ecosystem service use. Glob Environ Chang 1(34):218-226. https://doi.org/10.1016/j.gloenvcha.2015. 07.008

Helliwell JF (2003) How's life? Combining individual and national variables to explain subjective well-being. Econ Model 20(2):331-360. https://doi.org/10.1016/S0264-9993(02)00057-3

Hicks CC, Cinner JE (2014) Social, institutional, and knowledge mechanisms mediate diverse ecosystem service benefits from coral reefs. Proc Natl Acad Sci U S A 111(50):17791-17796. https://doi.org/10. 1073/pnas.1413473111

Hojman DA, Miranda Á (2018) Agency, human dignity, and subjective well-being. World Dev 101:1-15. https://doi.org/10.1016/j. worlddev.2017.07.029

Hossain MS, Dearing JA, Rahman MM, Salehin M (2016) Recent changes in ecosystem services and human well-being in the Bangladesh coastal zone. Reg Environ Chang 16(2):429-443. https://doi.org/10. 1007/s10113-014-0748-z

Howe C, Suich H, van Gardingen P, Rahman A, Mace GM (2013) Elucidating the pathways between climate change, ecosystem services and poverty alleviation. Curr Opin Environ Sustain 5(1):102107. https://doi.org/10.1016/j.cosust.2013.02.004

Islam N (2010) Integrated protected area co-management project summary: a study of the principal marketed value chains derived from the Sundarbans Reserved Forest. International Resources Group, Washington, D.C.
Islam MM, Herbeck J (2013) Migration and translocal livelihoods of coastal small-scale fishers in Bangladesh. J Dev Stud 49(6):832845. https://doi.org/10.1080/00220388.2013.766719

Ito $S$ (2002) From rice to prawns: economic transformation and agrarian structure in rural Bangladesh. J Peasant Stud 29(2):47-70. https:// doi.org/10.1080/714003949

Janssen MA, Anderies JM, Ostrom E (2007) Robustness of socialecological systems to spatial and temporal variability. Soc Nat Resour 20(4):307-322. https://doi.org/10.1080/ 08941920601161320

Jülich S (2011) Drought triggered temporary migration in an east Indian village. Int Migr 49(s1):e189-e199. https://doi.org/10.1111/j.14682435.2010.00655.x

Khandker SR (2012) Seasonality of income and poverty in Bangladesh. J Dev Econ 97(2):244-256. https://doi.org/10.1016/j.jdeveco.2011. 05.001

Kirchhoff T (2012) Pivotal cultural values of nature cannot be integrated into the ecosystem services framework. Proc Natl Acad Sci U S A 109(46):E3146-E3146. https://doi.org/10.1073/pnas.1212409109

Klasen S, Lahoti R (2016) How serious is the neglect of intra-household inequality in multi-dimensional poverty indices? Available at SSRN: https://doi.org/10.2139/ssrn.2742083

Lein H (2009) The poorest and most vulnerable? On hazards, livelihoods and labelling of riverine communities in Bangladesh. Singap J Trop Geogr 30(1):98-113. https://doi.org/10.1111/j.1467-9493.2008. 00357. $\mathrm{x}$

Lenhardt A, Shepherd A (2013) What has happened to the poorest 50\%? Brooks World Poverty Institute Working Paper No. 184. University of Manchester: Manchester

Lerner H, Berg C (2015) The concept of health in One Health and some practical implications for research and education: what is One Health? Infect Ecol Epidemiol 5(1):25300. https://doi.org/10.3402/ iee.v5.25300

Mahmud M, Sawada Y (2018) Happiness in life domains: evidence from rural Bangladesh. In: Sawada Y, Mahmud M, Kitano N (eds) Economic and social development of Bangladesh: miracle and challenges. Palgrave Macmillan, Cham. https://doi.org/10.1007/978-3319-63838-6 12

Markussen T, Fibæk M, Tarp F, Tuan NDA (2017) The happy farmer: self-employment and subjective well-being in rural Vietnam. J Happiness Stud 19(6):1613-1636. https://doi.org/10.1007/s10902017-9858-x

Martín-López B, Iniesta-Arandia I, García-Llorente M, Palomo I, Casado-Arzuaga I, Amo DG, Gómez-Baggethun E, Oteros-Rozas E, Palacios-Agundez I, Willaarts B, González JA, Santos-Martín F, Onaindia M, López-Santiago C, Montes C (2012) Uncovering ecosystem service bundles through social preferences. PLoS One 7(6): e38970. https://doi.org/10.1371/journal.pone. 0038970

McCulloch N, Baulch B (2000) Simulating the impact of policy upon chronic and transitory poverty in rural Pakistan. J Dev Stud 36(6): 100-130. https://doi.org/10.1080/00220380008422656

McGregor A, Coulthard S, Camfield L (2015) Measuring what matters: the role of wellbeing methods in development policy and practice. Development Progress project note 4. Overseas Development Institute: London

Millennium Ecosystem Assessment (MA) (2005) Ecosystems and human well-being: synthesis. World Resources Institute, Washington, DC

Nisbet EK, Zelenski JM, Murphy SA (2011) Happiness is in our nature: exploring nature relatedness as a contributor to subjective well-being. J Happiness Stud 12(2):303-322. https://doi.org/10.1007/ s10902-010-9197-7

Nussbaum (2001) Women and human development: the capabilities approach. Cambridge University Press, Cambridge

OECD (2013) OECD guidelines on measuring subjective well-being. OECD Publishing, Paris. https://doi.org/10.1787/9789264191655en 
Paprocki K (2015) Anti-politics of climate change. Himal Southasian 28(3):54-64

Paprocki K, Cons J (2014) Life in a shrimp zone: aqua-and other cultures of Bangladesh's coastal landscape. J Peasant Stud 41(6):1109-1130. https://doi.org/10.1080/03066150.2014.937709

Pascual U, Howe C (2018) Seeing the wood for the trees: exploring the evolution of frameworks of ecosystem services for human wellbeing. In: Schreckenberg K, Mace G, Poudyal M (eds) Ecosystem services and poverty alleviation: trade-offs and governance. Routledge, Oxford. https://doi.org/10.4324/9780429507090

Paul S, Islam MR (2015) Ultra-poor char people's rights to development and accessibility to public services: a case of Bangladesh. Habitat Int 48:113-121. https://doi.org/10.1016/j.habitatint.2015.03.018

Rahman PMM, Matsui N, Ikemoto Y (2013) Dynamics of poverty in rural Bangladesh. Springer, Tokyo. https://doi.org/10.1007/978-4431-54285-8

Raudsepp-Hearne C, Peterson GD, Bennett EM (2010) Ecosystem service bundles for analyzing tradeoffs in diverse landscapes. Proc Natl Acad Sci U S A 107(11):5242-5247. https://doi.org/10.1073/pnas. 0907284107

Rashid S, Minot N, Lemma S (2019) Does a "Blue Revolution" help the poor? Evidence from Bangladesh. Agr Econ 50(2):139-150

Renaud FG, Syvitski JPM, Sebesvari Z, Werners SE et al (2013) Tipping from the Holocene to the Anthropocene: how threatened are major world deltas? Curr Opin Environ Sustain 5(6):644-654. https://doi. org/10.1016/j.cosust.2013.11.007

Rigg J, Salamanca A, Phongsiri M, Sripun M (2018) More farmers, less farming? Understanding the truncated agrarian transition in Thailand. World Dev 107:327-337. https://doi.org/10.1016/j. worlddev.2018.03.008

Rodríguez JP, Beard TD, Bennett EM, Cumming GS, Cork S et al (2006) Trade-offs across space, time, and ecosystem services. Ecol Soc 11(1):28 https://www.ecologyandsociety.org/vol11/iss1/art28/

Ruitenbeek HJ (1996) Distribution of ecological entitlements: implications for economic security and population movement. Ecol Econ 17(1):49-64. https://doi.org/10.1016/0921-8009(95)00103-4

Sarker MH, Huque I, Alam M, Koudstaal R (2003) Rivers, chars and char dwellers of Bangladesh. Int J River Basin Manag 1(1):61-80. https://doi.org/10.1080/15715124.2003.9635193

Schreckenberg K, Mace G, Poudyal M (2018) Ecosystem services and poverty alleviation: trade-offs and governance. Oxford, Routledge. https://doi.org/10.4324/9780429507090

Sen (2001) Development as freedom. Oxford University Press, Oxford

Small N, Munday M, Durance I (2017) The challenge of valuing ecosystem services that have no material benefits. Glob Environ Chang 44: 57-67. https://doi.org/10.1016/j.gloenvcha.2017.03.005
Sultana N, Rayhan MI (2012) Coping strategies with floods in Bangladesh: an empirical study. Nat Hazards 64(2):1209-1218. https://doi.org/10.1007/s11069-012-0291-5

Summers JK, Smith LM, Case JL, Linthurst RA (2012) A review of the elements of human well-being with an emphasis on the contribution of ecosystem services. Ambio 41(4):327-340. https://doi.org/10. 1007/s13280-012-0256-7

Tengberg A, Fredholm S, Eliasson I, Knez I, Saltzman K, Wetterberg O (2012) Cultural ecosystem services provided by landscapes: assessment of heritage values and identity. Ecosyst Serv 2:14-26. https:// doi.org/10.1016/j.ecoser.2012.07.006

Tessler ZD, Vörösmarty CJ, Grossberg M, Gladkova I, Aizenman H et al (2015) Profiling risk and sustainability in coastal deltas of the world. Science 349(6248):638-643. https://doi.org/10.1126/science. aab3574

Toufique KA, Belton B (2014) Is aquaculture pro-poor? Empirical evidence of impacts on fish consumption in Bangladesh. World Dev 64:609-620. https://doi.org/10.1016/j.worlddev.2014.06.035

Toufique KA, Turton C (2003) Hands not land: how livelihoods are changing in rural Bangladesh. Bangladesh Institute of Development Studies, Dhaka

Vincent K (2007) Uncertainty in adaptive capacity and the importance of scale. Glob Environ Chang 17(1):12-24. https://doi.org/10.1016/j. gloenvcha.2006.11.009

Walker B, Holling CS, Carpenter SR, Kinzig A (2004) Resilience, adaptability and transformability in social-ecological systems. Ecol Soc 9(2):5 http://www.ecologyandsociety.org/vol9/iss2/art5/

White SC (2017) Relational wellbeing: re-centring the politics of happiness, policy and the self. Politics Policy 45(2):121-136. https://doi. org/10.1332/030557317X14866576265970

Wood G (2003) Staying secure, staying poor: the "Faustian bargain". World Dev 31(3):455-471. https://doi.org/10.1016/S0305$750 \mathrm{X}(02) 00213-9$

World Bank Group (2016) Dynamics of rural growth in Bangladesh: sustaining poverty reduction. Washington D.C, World Bank. https://doi.org/10.1596/978-1-4648-0876-0

Yang W, Dietz T, Liu W, Luo J, Liu J (2013) Going beyond the millennium ecosystem assessment: an index system of human dependence on ecosystem services. PLoS One 8(5):e64581. https://doi.org/10. 1371/journal.pone.0064581

Zhang K, Dearing JA, Dawson TP, Dong X, Yang X, Zhang W (2015) Poverty alleviation strategies in eastern China lead to critical ecological dynamics. Sci Total Environ 506:164-181. https://doi.org/ 10.1016/j.scitotenv.2014.10.096

Publisher's note Springer Nature remains neutral with regard to jurisdictional claims in published maps and institutional affiliations. 